\title{
The Inventory of Medicinal Plants Used by Kasepuhan Cibedug Banten as Encyclopedia-Based Learning Material
}

\author{
Surti Kurniasih*, Dina Dyah Saputri, Ninawati Dewi \\ Study Program of Biology Education, FKIP \\ Pakuan University \\ Bogor, Indonesia \\ *surti_kurniasih@unpak.ac.id
}

\begin{abstract}
Medicinal plants are natural ingredients that have been traditionally used for treatment based on experience. The aims of this study were to know the species and the parts of medicinal plants, as well as to understand how to obtain the medicinal plants and the processing technique of the medicinal plants. The methods used in this research were descriptive and explorative methods. The data was collected by purposive and snowball sampling with interview and direct observation. The result showed that twenty-nine medicine plants from twenty families. The most dominant family of medicinal plants was Zingiberaceae, with four species. The most used part of all medicinal plants were the leaf, only one plant which flower used as medicine. In general, processing technique of medicinal plants was boiling, seventeen medicinal plants with thetotal of percentage 56.68 percent. However, other processing technique also been used which were dropping, boiling, pounding, pressing, and smoothing with percentage of each processing technique was 3.33 percent. The outcome of the medicinal plants inventory is an encyclopedia that can be used as learning resources. Based on an expert validity results, it was concluded that the encyclopedia developed is suitable and adequate to be used as learning resources.
\end{abstract}

Keywords-encyclopedia, inventory, learning material, indigenous medicinal plants

\section{INTRODUCTION}

Diversity is the wealth of living being in an area either in the lowlands or in the ocean or other places. The level of Indonesia's biodiversity is included in the high category in the world, therefore Indonesia belongs the category of mega biodiversity countries [1]. One of the diversity owned by Indonesia is medicinal plants or better known as herbal plants [2]. Arsyah explained that the utilization of natural ingredients, both as medicine and for other purposes, tends to increase, particularly with current issue of back to nature [3]. One of the diversity that Indonesia has, namely medicinal plants, Gunung Halimun National Park (TNGH) is one of the mountains with various species of living being. Gunung Halimun National Park (TNGH) is located in two provinces, namely West Java and
Banten. Residential areas located in the northeast include Bogor Regency, in the northwestern is Lebak Regency, Banten, and in the south include Sukabumi Regency [4].

Kasepuhan Cibedug is indigenous community lives in the Mount Halimun National Park area. Based on the results of interviews, many members of Kasepuhan Cibedug Indigenous community still use traditional medicine. Some types of diseases that are treated with traditional medicine include diarrhea, fever, wounds, eye drops, itching, postpartum care, and others. The knowledge of plants used as medicine by the Kasepuhan Cibedug community has not been recorded properly. It is necessary to have an inventory of medicinal plants to increase knowledge, community welfare and as an effort to preserve tradition. The results of the medicinal plants inventory will be developed as a reference book in the form of a pictorial encyclopedia. Reference books on medicinal plants in addition to increasing public knowledge, can also be used in education, namely as a source of independent learning for students in Biodiversity material.

Encyclopedia is a book containing information arranged alphabetically. The advantages of the encyclopediaas a learning resource include easy to understand and provide detailed explanations as well as provide explanations that will be developed and have 3 general objectives, namely Source of Answers to Fact Questions, means encyclopedia has a role to answers questions that require facts and fact data. Source of Background Service, means encyclopedia as a source of information that contains topics and basic knowledge related to a subject that is useful for further knowledge. Direction service, is a service in directing further materials to the readers on the topics discussed, thus in this encyclopedia there are always references to the material that has been presented [5].

\section{MethodS}

The instruments used in this study were stationery, digital cameras, recording devices, and reference books including: Key to Plant Determination by Steenis 2013, Atlas of 
Medicinal Plants by Dalimatra 2003, Cultivation of Medicinal Plants by G. Kartasapoetra 2006. While, the materials used were all medicinal plant species used by the Kasepuhan Cibedug Indigenous community, inventory sheets and interview sheets. This research was conducted in the traditional village of Kasepuhan Cibedug Village, Lebak Regency, Banten. The research design was exploratory research with descriptive data presentation. The data collection technique was carried out by surveying through interviews and direct observation in the site. Interviews were addressed to village elders, traditional leaders, and community who had knowledge about the traditional utilization of medicinal plants in the research site, interviews were conducted using a questionnaire guide regarding plant species used as medicine, parts of medicinal plants used, processing technique and the function of each plant.

The techniques used in data collection were interviews, observation, documentation, and identification. Data collection was carried out by direct interviews using purposive sampling and snowball sampling. The data collection technique was performed by using purposive sampling. Whereas snowball sampling is a technique of determining the sample which is initially small in number, then gets bigger. Determination of the snowball sampling sample, first one or two people were selected but because the data provided by these two people was felt to be was insufficient and incomplete, the researchers looked for other people who were considered to have more knowledge and could complete the data provided by the two people previously until the number increased and the data gets saturated. Sampling was carried out using the roaming method, the plants in the inventory were 20 types of plants.

\section{RESULTS AND DISCUSSION}

\section{A. Results of the Medicinal Plants Inventory}

Based on the results of research that has been carried out in the Kasepuhan Cibedug Traditional Village, Lebak Banten Regency, the utilization of medicinal plants in Kasepuhan Cibedug Traditional Village is taught from generation to generation which need to be preserved as a very useful culture because it has proven its usefulness until present. Themedicinal plants used by the Kasepuhan Cibedug Indigenous community are 29 types of plants with 20 families which are presented in table 1 .

TABLE I. RESUlTS OF THE MEDICINAL PlANTS INVENTORY OF KASEPUHAN CIBEDUG INDIGENOUS COMMUNITY

\begin{tabular}{|c|c|c|c|c|c|c|}
\hline No & Family Name & Scientific Name & Local Name & Treatment & Used Part & Plant Quantity \\
\hline 1 & Apiaceae & Cantela asiatica & Antanan & Stop bleeding & Leaf & 6 \\
\hline \multirow[t]{2}{*}{2} & \multirow[t]{2}{*}{ Arecaceae } & Blumea balsamifera & Capeu & Appetite enhancer & Leaf & 4 \\
\hline & & $\begin{array}{l}\text { Ageratum } \\
\text { conyzoides }\end{array}$ & Jukut bau & External wounds & Leaf & 18 \\
\hline 3 & Campanulaceae & Isotoma longiflora & Kikorejat & Sore eyes & Flower & 14 \\
\hline 4 & Caricaceae & Carica papaya & Papaya & Digestion & Fruit & 6 \\
\hline 5 & Compositae & Mikunia cordata & Caputuher & $\begin{array}{l}\text { Wounds, } \\
\text { stomachache }\end{array}$ & $\begin{array}{l}\text { Leaf, stem, } \\
\text { and root }\end{array}$ & 4 \\
\hline 6 & Euphorbiaceae & $\begin{array}{l}\text { Sauropus } \\
\text { androgynus }\end{array}$ & Katuk & $\begin{array}{l}\text { Oral thrush and } \\
\text { heartburn }\end{array}$ & Leaf & 5 \\
\hline \multirow[t]{2}{*}{7} & \multirow[t]{2}{*}{ Fabaceae } & $\begin{array}{l}\text { Erythrina } \\
\text { lithosperma }\end{array}$ & Dadap & $\begin{array}{l}\text { Fever and stomach } \\
\text { ache }\end{array}$ & Leaf \& bark & 3 \\
\hline & & Cassia alata & Kateneng & $\begin{array}{l}\text { Itching and skin } \\
\text { disease }\end{array}$ & Leaf & 3 \\
\hline \multirow[t]{2}{*}{8} & \multirow[t]{2}{*}{ Lamiaceae } & $\begin{array}{l}\text { Coleus } \\
\text { scutellariorides }\end{array}$ & Jawer kotok & $\begin{array}{l}\text { Stop bleeding and } \\
\text { itching }\end{array}$ & Leaf & 10 \\
\hline & & $\begin{array}{l}\text { Orthosiphon } \\
\text { stamineus }\end{array}$ & Kumis kucing & Cold & Leaf & 8 \\
\hline 9 & Melastomataceae & $\begin{array}{l}\text { Melastoma } \\
\text { polyantum }\end{array}$ & Harendong & $\begin{array}{l}\text { Fever and stop } \\
\text { bleeding }\end{array}$ & $\begin{array}{l}\text { Leaf, root, and } \\
\text { fruit }\end{array}$ & 6 \\
\hline 10 & Meliaceae & Swietenia mahagoni & mahoni & Diabets & Bark & 2 \\
\hline 11 & Myrtaceae & Psidium guajava & Jambu batu & Diarrhea & fruit & 20 \\
\hline \multirow[t]{2}{*}{12} & \multirow[t]{2}{*}{ Oxalidaceae } & $\begin{array}{l}\text { Syzygium } \\
\text { polyanthum }\end{array}$ & Salam & High blood pressure & Leaf & 2 \\
\hline & & $\begin{array}{l}\text { Averrhoa } \\
\text { carambola }\end{array}$ & Belimbing & High blood pressure & Fruit & 4 \\
\hline 13 & Palmae & Arenga pinnata & Kawung & $\begin{array}{l}\text { Constipation and } \\
\text { kidney stones }\end{array}$ & Root & 1 \\
\hline 14 & Piperaceae & Piper betle & Seureuh & Eye iritation & Leaf & 3 \\
\hline \multirow[t]{2}{*}{15} & \multirow[t]{2}{*}{ Poaceae } & $\begin{array}{l}\text { Imperata } \\
\text { cylindrical }\end{array}$ & Eurih & Heartburn & Root & 12 \\
\hline & & $\begin{array}{l}\text { Cymbopogon } \\
\text { citratus }\end{array}$ & Seurai & Cold & Leaf and stem & 6 \\
\hline \multirow[t]{2}{*}{16} & \multirow[t]{2}{*}{ Rubiaceae } & Morinda citrifolia & Cangkudu & High blood pressure & Fruit & 4 \\
\hline & & Gardenia augusta & Kaca piring & Fever and diabets & Leaf & 3 \\
\hline 17 & Rutaceae & Citrua aurantiifolia & Jeruk nipis & Cough & Fruit & 3 \\
\hline
\end{tabular}


Table 1. Cont.

\begin{tabular}{|c|c|c|c|c|c|c|}
\hline 18 & Solanaceae & Physalis minima & Cecenet & $\begin{array}{l}\text { Fever and intestinal } \\
\text { worms }\end{array}$ & Root & 2 \\
\hline 19 & Verbenaceae & Lantana camara & Ceunte & $\begin{array}{l}\text { Fever and stop } \\
\text { bleeding }\end{array}$ & Leaf and root & 8 \\
\hline \multirow[t]{4}{*}{20} & \multirow[t]{4}{*}{ Zingiberaceae } & Zingiber officinale & Jahe & Fever and cold & Rhizome & 4 \\
\hline & & Curcuma domestika & Kunyit & Ulcer & Rhizome & 6 \\
\hline & & Alpinia purpurata & Laja gowah & Ringworm & Rhizome & 4 \\
\hline & & Zingiber zerumbet & Lampuyang & Diarrhea & Rhizome & 2 \\
\hline
\end{tabular}

Kasepuhan Cibedug Traditional Village is one of the traditional villages belonging to West Citorek Village which is located in the Halimun Lebak Mountain Area - Banten. Based on the results of previous observations, it is known that the majority of Cibedug's indigenous community still maintain the tradition of using medicinal plants in traditional medicine. Kasepuhan Cibedug Indigenous Community use medicinal plants as traditional medicines from generation to generation from their ancestors or previous parents. Parts of medicinal plants used by the Kasepuhan Cibedug Indigenous Community are 5 types of fruit, 1 type of stem, 1 type of root, 2 types of seeds, 4 types of rhizome, 1 type of bark. The part of plant most widely used by the Kasepuhan Cibedug Indigenous Community is the leaf. Leaf is most widely used part of the plant with total of 14 types of plants. Kasepuhan Cibedug indigenous community utilizes the leaves for medicine because it is easy to obtain and easy to mix. According to Jalius and Muswita [6], the leaf organ is easier to use since we can easily extract the essence of the plant. In the leaf organs, there are also more types of chemical compounds that have medicinal properties, such as flavonoids, tannins, saponins, phenols and alkaloids. With this chemical contents, leaves have quite a lot of medicinal potential [7]. The utilization of leaf as part of treatment, beside not destroying medicinal plant species, it is easiest part of plant to obtain, easy to process and easy to mix compared to other parts and is the part that contains medicinal substances due the food-making process occurs here. Meanwhile, the least used plant organ is flower because according to the community, only 1 medicinal plant which flower is used for medicine.

Residents of Kasepuhan Cibedug traditional village mostly process medicinal plants by mixing, namely dropping, boiling, pounding, mashing and pasting as many as 23 types of plants with a percentage of $80 \%$. Processing of medicinal plants that is often used by Kasepuhan Cibedug indigenous community is boiling, because this type of processing can reduce bland and bitter taste compared to being eaten directly and it is more sterile because can kill germs or pathogenic bacteria. The purpose of boiling medicinal plants is to transfer nutritious substances in plants into a water solution, then drink them for medicinal needs [8]. Meanwhile, the least processed is without being mixed or eaten directly as many as 6 types of plants with a percentage of $20 \%$. Medicinal plants that are consumed directly have better efficacy than the one had been processed first such as boiling. Due to the content of drugs consumed directly can be obtained better than the utilization by processing methods such as drinking boiled medicinal plant water.

Based on the inventory results, there are 29 types of medicinal plants from 20 families used by the Kasepuhan Cibedug Lebak, Banten. The type of plant that is most widely used as medicine in Kasepuhan Cibedug Traditional Village is turmeric (Curcuma longa), because it is easy to cultivate and has properties in curing various diseases. According to Pranata [9] turmeric has an active compound, namely curcumin and has biological activities such as antioxidants, anti-inflammatory and antineoplastic. Turmeric can also be used by the community as a cooking spice, spices, food ingredients, preservatives, dyes, cosmetics and raw materials for paints and turmeric also has a very big role in the health sector, which can be used as herbs and herbal medicine [10]

\section{B. Producing Encyclopedia Teaching Materials}

Based on the research results conducted on the Medicinal Plants Inventory in Kesepuhan Cibedug Traditional Village, it was then developed into a biology reference book for High School class $\mathrm{X}$ in the form of encyclopedia. The results of the medicinal plants inventory can increase knowledge of students in the teaching and learning process in schools. Students can be taught to take advantage of medicinal plants around them. In addition, students can expand their knowledge about medicinal plants to help people who still has insufficient knowledge on this matter. Producing an encyclopedia in print media with a size $(21 \times 29 \mathrm{~cm})$. Producing stodyboard produces a list of components contained in based on local potential encyclopedia is shown in Table 2. 
TABLE II. PRODUCING STODYBOARD PRODUCES LIST OF COMPONENTS IN BASED ON LOCAL POTENTIAL ENCYCLOPEDIA

\begin{tabular}{|l|l|l|l|}
\hline No & Encyclopedia Components & \multicolumn{1}{|c|}{ Sub Components } & \multicolumn{1}{c|}{ Description } \\
\hline 1 & Front cover & Name of media & Based on Local Potential Encyclopedia \\
\hline & & Title & $\begin{array}{l}\text { Kasepuhan } \\
\text { Plants }\end{array}$ \\
\hline & & Name of writer & Surti Kurniasih, Dina Dyah Saputri, Ninawati Dewi \\
\hline & Contents & Editorial & Foreword \\
\hline & & & Table of contents \\
\hline & & & Illustration (an image that represents the material) \\
\hline & & Material & Make up sentences that represent the material \\
\hline & & Reference & Core competencies (KI) and Basic Competences (KD) \\
\hline 3 & Back cover & Biography & Reference \\
\hline
\end{tabular}

\section{Encyclopedia Validation}

The book that has been compiled was then subject to expert validation to measure the suitability of the book content, the completeness of the components, language usage and the visual presentation of the encyclopedia. Book validation was carried out by 2 experts covering the content, language usage, and the media presented. Validation was carried out to determine the feasibility of the encyclopedia using the validation result instrument. The validation results are presented in Table 3 .

TABLE III. RESULTS OF EXPERT VALIDATION ON THE DEVELOPED ENCYCLOPEDIA

\begin{tabular}{|l|l|l|l|l|l|}
\hline \multirow{2}{*}{ No } & \multicolumn{1}{|c|}{ Aspect } & \multicolumn{2}{|c|}{ P (100\%) } & \multirow{2}{*}{ Average } & \multirow{2}{*}{ Criteria } \\
\cline { 3 - 6 } & & \multicolumn{1}{|l|}{$\boldsymbol{V 1}$} & $\boldsymbol{V 2}$ & & \\
\hline 1 & $\begin{array}{l}\text { Suitability of book } \\
\text { content }\end{array}$ & $80,55 \%$ & $88.89 \%$ & $84.89 \%$ & Valid \\
\hline 2 & Visual presentation & $84,61 \%$ & $90.38 \%$ & $82.50 \%$ & Valid \\
\hline 3 & Language usage & $75 \%$ & $95.83 \%$ & $85.42 \%$ & Valid \\
\hline & Average & & & $84,27 \%$ & \\
\hline & Category & & & & Valid \\
\hline
\end{tabular}

As can be seen in Table 3, it is known that the validation of the encyclopedia on the aspects of the suitability include the book content, visual presentation and language usage scores above 80 and is included in the valid category with few revisions. The book content suitability shows that in terms of material, the book is suitable to be used to increase students' knowledge about biodiversity topic. The visual presentation aspect of book is to determine the attractiveness of the encyclopedia since it can foster student motivation to read it. The language usage aspect is carried out to determine the ease of students to understand the material contained in the book. The valid category achieved by encyclopedia teaching materials based on local potential can be due to this media has strength point in terms of appearance, namely layout and design. The encyclopedia looks interesting because it is packed in a more modern way with a background and pictures of local potential medicinal plants of Kasepuhan Cibedug Indigenous community, the use of color variations is not monotonous. This kind of display can provide visual stimulation, can attract students' interest in learning, and can help streamline the learning process. Cimer stated that the use of biology learning media is able to display objects visually can make biology learning more interesting, effective, and the knowledge obtained is remembered longer [11].

Encyclopedia, apart from being superior in terms of visual presentation that can foster motivation to learn, can also facilitate students' understanding of biology concept, particularly the concept of Biodiversity. Biodiversity material is one of the materials that has many examples of species that must be distinguished based on plant diversity that can be used as medicine, classification, description, which requires a clear, real, and interesting visualization of objects. This can be accommodated by based on local potential encyclopedia media, because this media can display pictures of local plants often encountered by students in the surrounding environment and juxtaposed with materials that support the existence of these objects. Although it had numerous strength, there were also several things need to be improved regarding the validity of the encyclopedia. Things need to be improved included errors in writing material and writing scientific terms, the pictures used must be clear. The flaws of this encyclopedia were then corrected, thus the product validity criteria could be met and the product was declared valid, which meant that the encyclopedia was of good quality and all the components contained in it were suitable for use in the learning process.

In terms of visual presentation, this media had several strengths in terms of aesthetic. This is reflected in the design of the front cover, the content containing local pictures that are easy for students to find in their surroundings, and arranged systematically with a more attractive design. Yogiyatno and Sofyan [12], the practical aspect of a learning media, mainly belonging to a media group, is closely related to the design of the learning media. A learning resource design while learning will work effectively and increase the curiosity of students if the display of learning resources looks attractive or visual aesthetic, clear and systematic. Another advantage of an encyclopedia is that learning media in the form of an encyclopedia can improve student learning outcomes [13]. Encyclopedias can improve students' understanding of material, find facts about abstract material and make it easier for students to remember long-term material so that learning outcomes can increase [14]. 


\section{CONCLUSION}

Based on the research results on the inventory of medicinal plants in Kasepuhan Cibedug Traditional Village as a reference book in the form of an encyclopedia for high school level education, the following conclusions can be drawn:

- There are 29 types of medicinal plants from 20 families in Kasepuhan Cibedug Traditional Village. The most widely used medicinal plant organ is the leaf.

- Based on the results of expert validation, the results of the medicinal plants inventory in Kasepuhan Cibedug Traditional Village are suitable to be used as encyclopedia teaching materials.

\section{REFERENCES}

[1] S. Sutarno, "Rekayasa Genetik Dan Perkembangan Bioteknologi Di Bidang Peternakan," in Proceeding Biology Education Conference: Biology, Science, Enviromental, and Learning, 2016, vol. 13, no. 1, pp. 23-27.

[2] W. Wardiah, H. Hasanuddin, and M. Muthmainnah, "Etnobotani Medis Masyarakat Kemukiman Pulo Breuehselatan Kecamatan Pulo Aceh Kabupaten Aceh Besar,” J. EduBio Trop., vol. 3, no. 1, 2015.

[3] D.C. Arsyah, "Kajian Etnobotani Tanaman Obat (Herbal) Dan Pemanfaatannya Dalam Usaha Menunjang Kesehatan Keluarga Di Dusun Turgo, Purwobinangun, Pakem, Sleman," Skripsi Prodi Biol. Fak. Sains dan Teknol. Sleman, 2014.

[4] Dinas kehutanan dan Perkebunan Provinsi Banten, "Selayang Pandang," 2012. http://dishutbun.bantenprov.go.id/read/article-detail/struktur- organisasi/16/selayang-pandang-dinas- kehutanan-dan-perkebunanprovinsi-banten.html.

[5] W. Suwarno, "Perpustakaan Dan Buku: Wacana Penulisan \& Buku." Jogjakarta: Ar-Ruzz Media, 2011.

[6] J. Jalius and M. Muswita, "Eksplorasi Pengetahuan Lokal Tentang Tumbuhan Obat Di Suku Batin, Jambi,” Biospecies, vol. 6, no. 1, 2013.

[7] D. Yulianti, K. Kasrina, and A. Ruyani, "Etnobotani Tumbuhan Pekarangan Sebagai Obat Tradisional Masyarakat Suku Serawai Kelurahan Dusun Baru Kabupaten Seluma Bengkulu Dalam Pengembangan Sumber Belajar Biologi SMA.” Universitas Bengkulu, 2014.

[8] Novitasiah, "Kajian Etnofarmakognosi Dan Etnofarmakologi Penggunaan Tumbuhan Obat Di Desa Cisangkal Kecamatan Cihurip Kabupaten Garut," Farm. Bahari, vol. 5, no. 2, pp. 1-19, 2014.

[9] S.T. Pranata, "Herbal Toga (Tanaman Obat Keluarga)," Yogyakarta: Aksara Sukses, 2014.

[10] S.Y. Hartati, "Khasiat Kunyit Sebagai Obat Tradisional Dan Manfaat Lainnya," War. Penelit. dan Pengemb. Tanam. Ind., vol. 19, no. 2, pp. 5-9, 2013.

[11] A. Cimer, "What Makes Biology Learning Difficult and Effective: Students' Views," Educ. Res. Rev., vol. 7, no. 3, p. 61, 2012.

[12] W. Yogiyatno and H. Sofyan, "Pengembangan Multimedia Interaktif Kompetensi Dasar Mengoperasikan Software Basis Data Untuk SMK Negeri 1 Seyegan,” J. Pendidik. Vokasi, vol. 4, no. 1, 2014.

[13] A. Hidayat, S. Saputro, and J.S. Sukardjo, "Pengembangan Media Pembelajaran Ensiklopedia Hukum-Hukum Dasar Kimia Untuk Pembelajaran Kimia Kelas X SMAN 1 Boyolali Dan SMAN 1 Teras,” J. Pendidik. Kim., vol. 4, no. 2, pp. 47-56, 2015.

[14] R.A. Rizky and M.I. Damayanti, "Pengembangan Ensiklopedia Sumber Daya Alam Indonesia Untuk Meningkatkan Hasil Belajar Materi Sumber Daya Alam Siswa Kelas IV Sdn Jajartunggal III Kecamatan Wiyung Kota Surabaya." State University of Surabaya. 